\author{
Aleksander Bobko \\ Sekretarz Stanu w Ministerstwie Nauki i Szkolnictwa Wyższego
}

\title{
REFLEKSJE NA 40-LECIE WYDZIAtU FILOZOFICZNEGO UPJPII
}

Rocznice, zarówno prywatne, jak i instytucjonalne, skłaniają do refleksji. 40-lecie Wydziału Filozoficznego UPJP II w Krakowie daje dobrą okazję do namysłu nad dorobkiem tej niezwykłej instytucji zwłaszcza dla kogoś, kto jak ja przez 35 lat swojej aktywności naukowej związany był ze wspólnotą filozoficzną, funkcjonującą kolejno na Wydziale Teologicznym, potem na Papieskiej Akademii Teologicznej i wreszcie na Uniwersytecie Papieskim Jana Pawła II w Krakowie.

Dla mnie przygoda z filozofią rozpoczęła się w roku 1980, gdy jako student informatyki AGH zostałem zainspirowany do podjęcia dodatkowo studiów filozoficznych na krakowskim Wydziale Teologicznym. Było to możliwe dzięki otwarciu się ówczesnych władz Wydziału na kształcenie osób świeckich, co stanowiło realizację myśli kardynała Karola Wojtyły. Funkcjonowanie w tym środowisku w latach osiemdziesiątych było dla mnie pasjonującym doświadczeniem. Duch tamtego czasu kształtowany był z jednej strony przez dwa nadzwyczajnie pozytywne wydarzenia: wybór Karola Wojtyły na papieża i fenomen Solidarności roku 1980. Z drugiej strony, w grudniu 1981 roku nastąpiła reakcja w postaci stanu wojennego z wszystkimi jego konsekwencjami. Przestrzeń życia akademickiego Papieskiej Akademii Teologicznej wyrastała jak gdyby „na przecięciu” tych historycznych wydarzeń. I jest w tym jakiś paradoks, że ówczesne wykłady, seminaria, dysputy, które miały miejsce w nie do końca sformalizowanej instytucji (warto przypomnieć, ze Papieska Akademia Teologiczna nie była wtedy uznawana przez państwo, a nawet na używanie jej 
nazwy nałożona została cenzura), odbywały się w bardzo ubogich pomieszczeniach, do dziś stanowią dla mnie niedościgniony wzór akademickiej głębi, rzetelności, wolności, a także bezinteresowności w dążeniu do prawdy.

Po odzyskaniu przez Polskę niepodległości w roku 1989 zmienił się status Papieskiej Akademii Teologicznej. Oprócz formalnego uznania i dofinansowaniem działalności przez państwo nastąpiła także swoista stabilizacja instytucjonalna. Dla mnie osobiście okres lat dziewięćdziesiątych wiązał się ze zdobywaniem kolejnych stopni naukowych, rozwojem kontaktów krajowych i międzynarodowych, wychowywaniem pierwszych uczniów. Akademia i Wydział Filozoficzny zaczęły już coraz bardziej funkcjonować w normalnym trybie szkolnictwa wyższego w Polsce. Jako ekskluzywna uczelnia katolicka PAT miał poczucie swojej specyficznej misji - kształcenie duchownych i laikatu, badania relacji nauka-wiara, rozwijanie nauki społecznej Kościoła czy dbanie o ochronę chrześcijańskiego dziedzictwa narodowego. Jednak stopniowo ta ekskluzywność była wypierana przez coraz bardziej sformalizowany system, któremu zwłaszcza w ostatniej dekadzie zostały poddane wszystkie polskie uniwersytety.

Stąd też w dniu dzisiejszym Uniwersytet Papieski Jana Pawła II stoi przez podobnymi dylematami, jak inne uniwersytety w Polsce, a także w świecie. Wiele można by mówić o zmianach modelu uniwersytetu, które nastąpiły w ostatnim dwudziestoleciu: autonomiczny uniwersytet oparty na fundamencie jedności badań naukowych i kształcenia wszedł dzisiaj w nowy etap. Stał się elementem bardzo złożonego systemu nauki i szkolnictwa wyższego, który ma do spełnienia przynajmniej kilka funkcji: badania naukowe - innowacje (wprowadzane do gospodarczego i społecznego obiegu przez centra transferu technologii) - nauczanie - funkcja socjalna (zagospodarowywanie wolnego czasu młodzieży, co zmniejsza bezrobocie i jest elementem polityki socjalnej państwa). Sytuacja ta sprawia, że obecnie instytucje naukowe muszą w jakimś stopniu na nowo formułować swoją misję, zdefiniować własną tożsamość oraz określić miejsce i funkcję we współczesnej globalnej, dynamicznie zmieniającej się kulturze i gospodarce.

Chciałbym życzyć Uniwersytetowi Papieskiemu Jana Pawła II w Krakowie, a więc mojej Alma Mater, aby w tym procesie tworzenia misji na miarę XXI wieku potrafił twórczo sięgnąć do swoich korzeni, aby w nowoczesny świat przenosił te wartości, które stanowiły o jego ekskluzywności i wielkości zwłaszcza w pierwszych latach funkcjonowania. Zarówno nauka polska, jak i polski Kościół bardzo tego potrzebują. 